\title{
ACVRL1 wt Allele
}

National Cancer Institute

\section{Source}

National Cancer Institute. ACVRL1 wt Allele. NCI Thesaurus. Code C51725.

Human ACVRL1 wild-type allele is located within 12q11-q14 and is approximately $14 \mathrm{~kb}$ in length. This allele, which encodes serine/threonine-protein kinase receptor R3 protein, is involved in receptor signal transduction. ACVRL1 deficiency causes hemorrhagic telangiectasia type 2, which is also also known as Rendu-Osler-Weber syndrome 2. 